\title{
Effective Management Strategy against Potato Late Blight Incited by Phytophthora infestans
}

\author{
Noorulla Haveri $^{1 *}$, K. Thulasiram ${ }^{1}$, K.R. Shashidhar ${ }^{1}$ and H.M. Santhosha ${ }^{2}$ \\ ${ }^{1}$ ICAR-Krishi Vigyan Kendra, Kolar, Karnataka, India \\ ${ }^{2}$ ICAR-Krishi Vigyan Kendra, Sirsi, Karnataka, India \\ *Corresponding author
}

\section{A B S T R A C T}

Keywords

Potato, Late blight

management,

Phytophthora infestans

and Bio-control agents

Article Info

Accepted:

18 August 2018

Available Online:

10 September 2018
The study was conducted to develop an effective management strategy against the devastating potato late blight. Of the three management modules tested in the field conditions for two consecutive growing seasons, rabi 2014-15 and rabi 2015-16, the module T3 consisting of soil application of bio-agents $(1 \mathrm{~kg}$ each talc formulation of Trichoderma harzianum and Pseudomonas fluorescens enriched in $100 \mathrm{~kg}$ well decomposed FYM) 15 days before planting, tuber treatment with Mancozeb @ 0.25\%, prophylactic spray with Mancozeb @ $0.2 \%$ twice at weekly interval before onset of the disease followed by curative sprays with Cymoxanil + Mancozeb @ 0.3\%, Dimethomorph @1.0\%+Mancozeb@0.2\%, and Fenamidone+ Mancozeb@0.3\% at weekly interval at onset of the disease was found most effective and recorded least disease severity and higher yield compared to other modules. Hence, this module serves as effective management strategy against the disease under field conditions.

\section{Introduction}

Potato, Solanum tuberosum L., is one of the most important starchy edible tuber crops in the world (Desjardins et al., 1995; Chycoski and Punja, 1996). In India, potato is a major vegetable crop grown in an area of 1.9 million hectare, with a total annual production of 45.3 million tones with the productivity of 22.70 t/ha (Anon., 2012). The potato crop is unfortunately susceptible to many plant diseases. Of the various diseases occurring in potato, the late blight caused by Phytophthora infestans (Mont.) de Bary is one of the most destructive disease affecting potato production world-wide including India (Chycoski and
Punja, 1996; Fry and Goodwin, 1997) and has been considered a threat to global food security (Cooke et al., 2012).

The potato growing region in northern parts of India has evidenced the annual and regular severity of late blight but was not the same case in southern parts, especially Karnataka prior to 2006 (Chowdappa et al., 2011). Post 2008, severe late blight occurrence has started occurring in major potato growing regions in south-west India including Karnataka, sometimes leading to cent per cent crop loss and it might be due emergence of A2 mating type (Chowdappa et al., 2013). In existence of new mating type under prevalence of 
congenial environmental conditions management of late blight has become increasingly difficult under field and storage conditions (Fry et al., 1992). The fungicidal management has played a vital role in curbing the late blight menace but under epidemic favoring environmental conditions the only curative fungicidal sprays have miserably failed to control the devastating problem. Further, the regular fungicidal use encourages the development of resistance in P. infestans, increases the production cost and more important being it is detrimental to the environment (Siddiqui et al., 2016).

From the above facts it is understood that, management of late blight is most challenging in successful potato production. Hence, it is necessary to develop eco-friendly and costeffective alternative management strategy against the disease. Effectiveness of prophylactic application of fungicides on onset of favorable environment before disease occurrence followed by curative sprays on disease onset have been reported by Manjunath et al., (2017) and Prasad et al., (2018). Further, most of the researchers have explored the possibility of using antagonistic bio-agents for suppression of $P$. infestans, further bio-control agents alone is not sufficient to provide complete protection under variable environment factors in field conditions (Yao et al., 2015). Therefore, the present study was conducted to evolve effective management strategy by taking into account the diverse strategies like soil application of bio-agents, fungicidal tuber treatment and need based prophylactic and curative fungicidal application.

\section{Materials and Methods}

The field experiment was conducted during Rabi crop season for two consecutive years, 2014-15 and 2015-16 by ICAR-Krishi Vigyan Kendra, Kolar, Karnataka, India (The experiments were conducted as a part of On Farm Testing - OFT). The experiment was laid out in randomized block design with three treatments and eight replications using late blight susceptible potato cultivar 'Kufri Jyoti'. The soil of the experimental plot was red sandy loam in texture. The crop was raised as per the agronomic practices recommended by University of Horticultural Sciences, Bagalkot, Karnataka (India). The treatment details are mentioned hereunder,

T1 - Indiscriminate spray of one or combination of two fungicide viz., Mancozeb @ 0.2\%, Dimethomorph @ 0.1\% + Metiram @ 0.2\%, Copper Oxy Chloride @ 0.3\%, Fenamidone + Mancozeb @ 0.3\%, Metalaxyl + Mancozeb @ 0.2\%, Cymoxanil + Mancozeb @ 0.3\%, Copper Hydroxide @ 0.2\%, Propineb@0.2\%, Chlorothalonil @ 0.2\% at weekly intervals starting from disease onset till completion of crop cycle.

T2 - Tuber treatment with Mancozeb (@0.25\%), prophylactic spray with Mancozeb @ $0.2 \%$ twice at weekly interval before onset of the disease, curative sprays with Metalaxyl + Mancozeb @ 0.2\% and Cymoxanil + Mancozeb @ 0.3\% at weekly interval at onset of the disease.

T3 - Soil application of bio-agents (Trichoderma harzianum and Pseudomonas fluorescens), Tuber treatment with Mancozeb (@0.25\%), prophylactic spray with Mancozeb @ $0.2 \%$ twice at weekly interval before onset of the disease, curative sprays with Cymoxanil + Mancozeb @ 0.3\%, Dimethomorph @ 1.0\% + Mancozeb@0.2\%, and Fenamidone + Mancozeb@0.3\% at weekly interval at onset of the disease.

For soil application of bio-agents, $1 \mathrm{~kg}$ each talc formulation of Trichoderma harzianum $\left(10^{8} \mathrm{cfu} / \mathrm{gram}\right)$ and Pseudomonas fluorescens ( $\left.2 \times 10^{8} \mathrm{cfu} / \mathrm{gram}\right)$ were mixed with $100 \mathrm{~kg}$ well 
decomposed farm yard manure (FYM) and allowed to multiply for 15 days with $25-30 \%$ moisture level under proper shade conditions (Shanthiyaa et al., 2013). This enriched FYM was applied to the field 15 days before planting. The tuber treatment was performed on the day of planting by dipping the potato seed tubers in Mancozeb (@0.25\%) fungicidal solution for 5 minutes later on shade dried and planted in the field. The prophylactic foliar sprays with fungicides were applied at the time of canopy closure i.e., $5^{\text {th }}$ week after planting before onset of disease whereas the curative foliar sprays at onset of disease.

The late blight disease severity assessments were made by following 1-9 severity scale (Malcolmson, 1976) and details of which are given in table 1 .

The disease index (\%) was computed using the following formula (McKinney, 1923).

Sum of all individual ratings Disease index $(\%)=$

Total no. of plants examined $\mathrm{x}$ Maximum score

About 20 plants in each treatment block were selected and disease severity observations were recorded at ten days intervals after first notice of disease. At harvest (90 days after planting) observations on blighted tubers and tuber yield ( $\mathrm{t} / \mathrm{ha}$ ) were also recorded. The original data was arc sine transformed and subjected to analysis of variances (ANOVA) and critical difference (CD) was used to separate the treatment means. The data were statistically analyzed by using Genstat $14^{\text {th }}$ edition developed by the Rothamsted research station, England.

\section{Results and Discussion}

The study was conducted to design the effective management strategy against potato late blight. To devise the same, different management modules were formulated by combining the various components viz., soil application of bio-agents, fungicidal tuber treatment, prophylactic and curative fungicidal sprays (Treatment details are mentioned in materials and methods section) and efficacy of these modules were tested in field condition for two consecutive years (Rabi 2014-15 and Rabi 2015-16). The disease severity (\%) data was recorded at 10 days interval starting from 45 days after planting (DAP) up to 85 DAP.

During the Rabi 2014-15, the module T3 (soil application of bio-agents, fungicidal tuber treatment, prophylactic and curative fungicidal sprays) recorded significantly least disease severity $(7.29 \%$ ) followed by T2 (fungicidal tuber treatment, prophylactic and curative fungicidal sprays) (14.93\%) and significantly highest disease severity of $18.75 \%$ was noted in T1 (Indiscriminate curative fungicidal sprays) at 45 DAP.

The similar trend was observed at 55, 65, 75 and 85 DAP. Additionally, the progress in disease severity in T3 from 45 to 85 DAP was very slow compared to other modules. In total, the significantly lowest mean disease severity of 11.82 per cent was recorded with T3 followed by T2 (18.71\%) and the module T1 was found least effective and exhibited the significantly highest mean disease severity (24.94\%) (Table 2).

The effect of these modules in management of potato late blight followed the similar trend even during Rabi 2014-15 as well. Wherein, T3 was found significantly superior with least mean disease severity (15.61\%) followed by T2 $(22.54 \%)$ and T1 was found significantly least effective $(28.14 \%)$. Additionally, the progress in disease severity in $\mathrm{T} 3$ from 45 to 85 DAP was very slow compared to other modules (Table 3). Interestingly the similar trend was noted in pooled data, in which T3 
was found most effective followed by $\mathrm{T} 2$. Further, T1 was noted to be least effective in managing the potato late blight (Table 4).

These modules were also found effective in controlling the progression of the disease to tubers wherein the $\mathrm{T} 3$ recorded least quantity of blighted tubers $(0.14 \mathrm{t} / \mathrm{ha})$ at harvest followed by T2 (0.24 t/ha) and T1 was found significantly least effective $(0.45 \mathrm{t} / \mathrm{ha})$ during rabi 2014-15. Similar trend was noticed during rabi 2015-16 and even in pooled data. Further, these modules had positive effect on tuber yield and economics. During rabi 201415, T3 recorded significantly highest yield (24.32 t/ha) and B: C ratio (1.54). Whereas $\mathrm{T} 1$ recorded significantly lowest yield of 20.10 t/ha and B: C ratio of 1.22. Similar trend was noticed during rabi 2015-16 and even in pooled data (Table 5).

The current study demonstrates that, the T3 module was found significantly most effective in controlling potato late blight under field conditions. The results are in conformity with the findings of Manjunath et al., (2017) who demonstrated the additive effect between various components of IDM viz., soil application of bio-agents, fungicidal tuber treatment, prophylactic fungicidal spray followed by curative fungicidal sprays in potato late blight management compared to individual components. Similarly, Chakraborty and Banerjee (2016) reported the greatest reduction in potato late blight severity in treatment having prophylactic spray with mancozeb@0.2\% followed by curative spray with fenamidone + manozeb @0.3\% thrice at weekly intervals. Further, Sharma and Saikia (2013) were of similar opinion that, prophylactic spray with Mancozeb @ $0.25 \%$ followed by curative sprays with Cymoxanil + Mancozeb@0.3\% and Dimethomorph@ $0.1 \%$ resulted in effective management of the potato late blight disease.

In the present study, soil application of Trichoderma harzianum and Pseudomonas fluorescens lead to better management of the disease in terms of reduced disease severity and least amount of blighted tubers. This is in agreement with the report of Yao et al., (2015), who demonstrated the field efficacy of Trichoderma isolate HNA14 in management of potato late blight. Similarly, El-Naggar et al., (2016) also noted the cumulative effect of $B$. subtilis, $P$. fluorescens, T. harzianum and $T$. viride in reducing the potato late blight severity. The presence of $P$. fluorescens and $T$. harzianum in the rhizosphere, the mycelium and other propogules of pathogen present in the tuber and rhizospheric region seemed to be parasitized by the bio-agents (Shanthiyaa et al., 2013). Further, depletion of essential nutrients at the point of contact, fast and high rate of sporulation and colonization capacity of bio-agents may have suppressed the infection by pathogen (Yao et al., 2015).

Table.1 Late blight disease severity assessments scale

\begin{tabular}{|c|c|}
\hline Plant area infected $(\boldsymbol{\%})$ & Score \\
\hline Trace of infection & 9 \\
\hline$<10$ & 8 \\
\hline $11-25$ & 7 \\
\hline $26-40$ & 6 \\
\hline $41-60$ & 5 \\
\hline $61-70$ & 4 \\
\hline $71-80$ & 3 \\
\hline $81-90$ & 2 \\
\hline Collapsed & 1 \\
\hline
\end{tabular}


Table.2 Severity of potato late blight in the field experiment (On farm testing) conducted during Rabi 2014-15

\begin{tabular}{|c|c|c|c|c|c|c|}
\hline \multirow[t]{2}{*}{ Modules } & \multicolumn{6}{|c|}{ Disease severity (\%) } \\
\hline & 45 DAP & 55 DAP & 65 DAP & 75 DAP & 85 DAP & Mean \\
\hline T1 & $\begin{array}{c}18.75 \\
(25.67)^{*}\end{array}$ & $\begin{array}{c}24.31 \\
(29.54)\end{array}$ & $\begin{array}{c}34.86 \\
(36.20)\end{array}$ & $\begin{array}{c}27.57 \\
(31.68)\end{array}$ & $\begin{array}{c}19.24 \\
(26.02)\end{array}$ & $\begin{array}{c}24.94 \\
(29.98)\end{array}$ \\
\hline $\mathbf{T 2}$ & $\begin{array}{c}14.93 \\
(22.74)\end{array}$ & $\begin{array}{c}18.40 \\
(25.40)\end{array}$ & $\begin{array}{c}24.44 \\
(29.63)\end{array}$ & $\begin{array}{c}19.65 \\
(26.32)\end{array}$ & $\begin{array}{c}16.11 \\
(23.67)\end{array}$ & $\begin{array}{c}18.71 \\
(25.64)\end{array}$ \\
\hline T3 & $\begin{array}{c}7.29 \\
(15.56)\end{array}$ & $\begin{array}{c}14.24 \\
(22.17)\end{array}$ & $\begin{array}{c}16.25 \\
(23.78)\end{array}$ & $\begin{array}{c}12.01 \\
(20.28)\end{array}$ & $\begin{array}{c}9.31 \\
(17.77)\end{array}$ & $\begin{array}{c}11.82 \\
(20.12)\end{array}$ \\
\hline S.Em. \pm & 0.44 & 0.38 & 0.43 & 0.29 & 0.21 & - \\
\hline CD (0.05) & 1.34 & 1.14 & 1.33 & 0.89 & 0.63 & \\
\hline $\mathrm{CV}(\%)$ & 10.86 & 9.14 & 9.04 & 8.13 & 7.62 & \\
\hline
\end{tabular}

*Values in parentheses are arc sine transformed

Treatment details are given in materials and methods section.

Table.3 Severity of potato late blight in the field experiment (On farm testing) conducted during Rabi 2015-16

\begin{tabular}{|c|c|c|c|c|c|c|}
\hline \multirow[t]{2}{*}{ Modules } & \multicolumn{6}{|c|}{ Disease severity (\%) } \\
\hline & 45 DAP & 55 DAP & 65 DAP & 75 DAP & 85 DAP & Mean \\
\hline $\mathbf{T 1}$ & $\begin{array}{c}17.78 \\
(24.95)^{*}\end{array}$ & $\begin{array}{c}28.19 \\
(32.05)\end{array}$ & $\begin{array}{c}39.17 \\
(38.76)\end{array}$ & $\begin{array}{c}33.68 \\
(35.48)\end{array}$ & $\begin{array}{c}21.88 \\
(27.89)\end{array}$ & $\begin{array}{c}28.14 \\
(32.05)\end{array}$ \\
\hline $\mathbf{T} 2$ & $\begin{array}{c}16.88 \\
(24.26)\end{array}$ & $\begin{array}{c}24.79 \\
(29.87)\end{array}$ & $\begin{array}{c}29.72 \\
(33.04)\end{array}$ & $\begin{array}{c}21.46 \\
(27.60)\end{array}$ & $\begin{array}{c}19.86 \\
(26.47)\end{array}$ & $\begin{array}{c}22.54 \\
(28.36)\end{array}$ \\
\hline T3 & $\begin{array}{c}10.49 \\
(18.86)\end{array}$ & $\begin{array}{c}19.17 \\
(25.97)\end{array}$ & $\begin{array}{c}21.81 \\
(27.84)\end{array}$ & $\begin{array}{c}15.63 \\
(23.27)\end{array}$ & $\begin{array}{c}10.97 \\
(19.35)\end{array}$ & $\begin{array}{c}15.61 \\
(23.28)\end{array}$ \\
\hline S.Em. \pm & 0.32 & 0.51 & 0.43 & 0.40 & 0.27 & - \\
\hline CD (0.05) & 0.98 & 1.56 & 1.31 & 1.22 & 0.81 & \\
\hline $\mathrm{CV}(\%)$ & 9.03 & 9.95 & 8.68 & 8.97 & 8.07 & \\
\hline
\end{tabular}

*Values in parentheses are arc sine transformed

Treatment details are given in materials and methods section. 
Table.4 Pooled data of potato late blight severity in the field experiments (On farm testing) conducted during Rabi 2014-15 and Rabi 2015-16

\begin{tabular}{|c|c|c|c|c|c|c|}
\hline \multirow[t]{2}{*}{ Modules } & \multicolumn{6}{|c|}{ Disease severity (\%) } \\
\hline & 45 DAP & 55 DAP & 65 DAP & 75 DAP & 85 DAP & Mean \\
\hline T1 & $\begin{array}{c}18.26 \\
(25.31)^{*}\end{array}$ & $\begin{array}{c}26.25 \\
(30.81)\end{array}$ & $\begin{array}{c}37.01 \\
(37.49)\end{array}$ & $\begin{array}{c}30.63 \\
(33.61)\end{array}$ & $\begin{array}{c}20.56 \\
(26.96)\end{array}$ & $\begin{array}{c}26.54 \\
(31.02)\end{array}$ \\
\hline T2 & $\begin{array}{c}15.90 \\
(23.51)\end{array}$ & $\begin{array}{c}21.60 \\
(27.70)\end{array}$ & $\begin{array}{c}27.08 \\
(31.36)\end{array}$ & $\begin{array}{c}20.56 \\
(26.97)\end{array}$ & $\begin{array}{c}17.99 \\
(25.10)\end{array}$ & $\begin{array}{c}20.63 \\
(27.03)\end{array}$ \\
\hline T3 & $\begin{array}{c}8.89 \\
(17.29)\end{array}$ & $\begin{array}{c}16.70 \\
(24.13)\end{array}$ & $\begin{array}{c}19.03 \\
(25.87)\end{array}$ & $\begin{array}{c}13.82 \\
(21.83)\end{array}$ & $\begin{array}{c}10.14 \\
(18.58)\end{array}$ & $\begin{array}{c}13.72 \\
(21.75)\end{array}$ \\
\hline S.Em. \pm & 0.35 & 0.44 & 0.42 & 0.31 & 0.23 & - \\
\hline CD (0.05) & 1.07 & 1.32 & 1.28 & 0.94 & 0.71 & \\
\hline CV $(\%)$ & 9.55 & 9.47 & 8.79 & 8.18 & 7.80 & \\
\hline
\end{tabular}

*Values in parentheses are arc sine transformed

Treatment details are given in materials and methods section.

Table.5 Blighted tubers and tuber yield of potato in field experiments conducted during Rabi 2014-15 and Rabi 2015-16

\begin{tabular}{|c|c|c|c|c|c|c|c|c|c|}
\hline \multirow[t]{2}{*}{ Modules } & \multicolumn{3}{|c|}{ Blighted tubers (t/ha) } & \multicolumn{3}{|c|}{ Yield (t/ha) } & \multicolumn{3}{|c|}{ B:C ratio } \\
\hline & 2014-15 & $2015-16$ & Pooled & 2014-15 & $2015-16$ & Pooled & 2014-15 & $2015-16$ & Pooled \\
\hline T1 & 0.45 & 0.56 & 0.51 & 20.10 & 16.20 & 18.15 & 1.25 & 1.20 & 1.22 \\
\hline $\mathrm{T} 2$ & 0.24 & 0.37 & 0.31 & 21.04 & 17.60 & 19.32 & 1.38 & 1.44 & 1.41 \\
\hline T3 & 0.14 & 0.19 & 0.16 & 24.32 & 19.43 & 21.87 & 1.56 & 1.51 & 1.54 \\
\hline S.Em. \pm & 0.03 & 0.06 & 0.04 & 0.53 & 0.45 & 0.57 & \multirow[t]{3}{*}{-} & \multirow[t]{3}{*}{-} & \multirow[t]{3}{*}{-} \\
\hline CD $(0.05)$ & 0.07 & 0.17 & 0.11 & 1.33 & 1.14 & 1.43 & & & \\
\hline $\mathrm{CV}(\%)$ & 5.23 & 4.57 & 4.07 & 8.31 & 7.16 & 7.33 & & & \\
\hline
\end{tabular}

Treatment details are given in materials and methods section.

Besides, the prior application of bio-agents may have induced the systemic resistance in potato plant which in turn leads to least severity of late blight (Harman et al., 2004; Ahmed et al., 2010).

The present investigation further demonstrated that, seed tuber treatment with mancozeb retarded the pathogen present in tuber and even in near vicinity in rhizosphere and hence leads to reduced disease severity. These findings are consistent with Hartill (1980) who recorded reduction in disease incidence and increases in yield in seed tuber treatment plots.
In the study, prophylactic sprays with mancozeb before onset of disease followed by curative sprays with Cymoxanil + Mancozeb, Dimethomorph + Mancozeb, and Fenamidone + Mancozeb at onset of disease proved to be most efficient in reducing the disease severity. These results are in line with findings of Sharma and Saikia (2013); Chakraborty and Banerjee (2016) and Manjunath et al., (2017). Upon onset of congenial weather for late blight development the prophylactic spray with mancozeb serve as protective layer on foliage and destroy the sporangia landed on the foliage thereby delaying in onset of the disease. Due to delay in onset of disease crop 
may escape most susceptible stage for the disease (Sobolewski and Robak, 2004) further slows down the development disease epidemic (Sharma and Saikia, 2013). Immediately on onset of disease curative sprays with Cymoxanil + Mancozeb, Dimethomorph + Mancozeb and Fenamidone + Mancozeb at weekly interval effectively check the disease progress. This finding was supported by Muchiri et al., (2009), Alexandrov (2011), Chakraborty and Mazumdar (2012). In this study it was also observed that the curative spray with Metalaxyl + Mancozeb was not found effective. It might be due to its continuous and increased use that might have led to the development of resistant strain of $P$. infestans (Ali and Dey, 1999; Singh et al., 2005).

In the present study, T3 module proved to be most effective as it consist of different approaches of disease management which are likely to be active during the entire crop cycle and turned out to be most efficient management strategy against the deadly potato late blight disease under field conditions.

\section{Acknowledgement}

Authors are sincerely thankful to ICAR Agricultural Technology Application Research Institute (ATARI), Zone XI, India for having provided financial and technical support to conduct this study.

\section{References}

Ahmed, A.S., Sanchez, C.P. and Candela, M.E. 2010. Evaluation of induction of systemic resistance in pepper plants (Capsicum annuum) to Phytopthora capsici using Trichoderma harzianum and its relation with capsidiol accumulation. European Journal of Plant Pathology, 106: 817824.
Alexandrov, V. 2011. Efficacy of some fungicides against late blight of tomato. Bulgarian Journal of Agricultural Science, 17 (4): 465-469.

Anonymous, 2012, www.cpri.in, Central Potato Research Institute, Shimla.

Chakraborty, A. and Banerjee, H. 2016. Effective management strategies against late blight of potato. SAARC Journal of Agriculture, 14(1): 111-117.

Chakraborty, A. and Mazumdar, D. 2012. Development of effective spray schedule for the management of late blight of potato in plains of West Bengal. Potato Journal, 39(1): 92-94.

Chowdappa P, Nirmal Kumar B.J., Madhura S. 2013. Emergence of 13-A2 Blue lineage of Phytophthora infestans was responsible for severe outbreaks of late blight on tomato in south-west India. Journal of Phytopathology, 161:49-58.

Chowdappa, P, Mohan Kumar S.P., Sanjeev S. and Singh, B.P. 2011. Integrated management of early and late blight of potato and tomato. ORP on Leaf Spot Diseases Series 17. Bangalore, India: Indian Institute of Horticultural Research.

Chycoski, C.I. and Punja, Z.K. 1996. Characteristics of populations of Phytophthora infestans from potato in British Columbia and other regions of Canada during 1993 to 1995. Plant Disease, 80: 579-589.

Cooke, D.E.L., Cano, L.M. and Raffaele, S. 2012. Genome analyses of an aggressive and invasive lineage of the Irish potato famine pathogen. PLoS Pathogens, 8:102114.

Desjardins A.E., McCormick, S.P. and Corsini, D.L. 1995. Diversity of sesquiterpenes in 46 potato cultivars and breeding selections. Journal of Agricultural and Food Chemistry, 43: 2267-2272.

El-Naggar, M.A., Abouleid, H.Z., El-Deeb, H.M., Abd-El-Kareem, F. and Elshahawy, I.E. 2016. Biological Control of Potato Late Blight by Means of Induction Systemic Resistance and Antagonism. Research Journal of Pharmaceutical, 
Biological and Chemical Sciences, 7(1): 1338-1348.

Fry, W.E. and Goodwin, S.B. 1997. Reemergence of potato and tomato late blight in the United States. Plant Disease, 81: 1349-1357.

Fry, W.E., Goodwin, S.B., Matuszak, J.M., Spielman, L.J., Milgroom, M.G. and Drenth, A. 1992. Population genetics and intercontinental migrations of Phytophthora infestans. Annual Review of Phytopathology, 30: 107-129.

Harman G.E., Latorre, B., Agosin, E., SanMartin, R., Riegel, D.G., Nielsen, P.A., Tronsmo, A. and Pearson, R.C. 1996. Biological and integrated control of Botrytis bunch rot of grape using Trichoderma spp. Biological Control, 7: 259-266.

Hartill, W.F.T. 1980. Spray and Seed Tuber Treatments for Late Blight Control in Potatoes. Plant disease, 64 (8): 764-766.

Malcolimson, J.F. 1976. Assessment of field resistance to late blight (Phytophthora infestans) in potatoes. Transactions of the British Mycological Society, 67: 321-325.

Manjunath, B., Devaraja, Srinivasappa, K.N., Vasanthi, B.G. and Manjunath Gowda. 2017. Assessment on management of late blight in potato incited by Phytophthora infestans. International Journal of Plant Protection, 10 (2): 410-414.

McKinney, H.H. 1923. Influence of soil temperature and moisture on infection of wheat seedlings by Helminthosporium sativum. Journal of Agricultural Research, 26: 195-217.

Muchiri, F.N., Nada, R.D., Aanya, O.M., Nyankanga R.O and Ariga, E.S. 2009. Efficacy of fungicide mixtures for the management of Phytophthora infestans (US-1) on Potato. Phvtoprotection, 90: 19-29.

Prasad, P.S., Amarananjundeswara, H., Soumya Shetty and Sandhya, G.C. 2018. Efficacy of different advanced fungicides against late blight of potato incited by Phytophthora infestans in southern Karnataka. International Journal of Chemical Studies, 2018; 6(2): 2174-2178.

Shanthiyaa, V., Saravanakumar, D., Rajendran, L., Karthikeyan, G., Prabakar, K. and Raguchander, T. 2013. Use of Chaetomium globosum for biocontrol of potato late blight disease. Crop Protection, 52: 33-38.

Sharma, P. and Saikia, M.K. 2013. Management of late blight of potato through chemicals. IOSR Journal of Agriculture and Veterinary Science, 2(2): 23-26.

Siddique, N.A, Aktar, M.S. and Swapon, N.H. 2016. Comparative efficacy of different fungicides against late blight diseases of potato incited by Phytophthora infestans (Mont.) de Bary and its Management. Journal of Plant Pathology and Microbiology, 7(7): 361-364.

Sobolewski, J. and Robak, J. 2004. New products used for complex disease control on tomato growing in open field. Progressive Plant Protection, 44: 11051107.

Yao, Y., Li, Y., Chen, Z., Zheng, B., Zhang, L. and Wang, Q. 2015. Biological control of potato late blight using isolates of Trichoderma. American Journal of Potato Research, DOI 10.1007/s12230-0159475-3.

\section{How to cite this article:}

Noorulla Haveri, K. Thulasiram, K.R. Shashidhar and Santhosha, H.M. 2018. Effective Management Strategy against Potato Late Blight Incited by Phytophthora infestans. Int.J.Curr.Microbiol.App.Sci. 7(09): 2688-2695. doi: https://doi.org/10.20546/ijcmas.2018.709.334 